\title{
A ICONOCLASTIA NO CINEMA E NA PEDAGOGÍAi. Reflexões a partir de dois filmes infantis dos anos de 1930
}

ICONOCLASM IN CINEMA AND PEDAGOGY.

Some thoughts on two children's films from the 1930s

\author{
LA ICONOCLASTIA EN EL CINE Y LA PEDAGOGÍA \\ Reflexiones a propósito de dos películas infantiles de los años '30
}

Ines Dussel $^{1}$

\begin{abstract}
RESUMO
A iconoclastia é uma parte da história das imagens em educação que considera sentidos múltiplos. Nas muitas e intensas paixões provocadas pelas imagens, destaca-se a iconoclastia como um sentimento forte que confere muitos poderes às imagens - uma reverência e um medo que leva ao ponto de destruí-las. Porém, a iconoclastia tem sido pouco estudada na história da educação. Neste artigo, proponho uma primeira aproximação entre a iconoclastia e a história da educação por meio da análise de dois filmes dos anos 1930 sobre crianças, Emil und die Detektive (Alemanha, Gerhard Lamprecht, 1931) e Zéro de conduite (França, Jean Vigo, 1933), que contêm várias cenas nas quais monumentos e outros ícones das autoridades tradicionais são profanados. A partir desses filmes, reflito sobre a ambivalência do gesto iconoclasta, como uma história da revolta contra as autoridades constituídas, mais também como um movimento que permanece em um círculo de "fascinação, repulsão, destruição, expiação... gerado pela adoração da imagem proibida" (LATOUR, 2010, p.70), um círculo a ser questionado se pretendemos abrir caminho para uma outra política do visual.
\end{abstract}

PALAVRAS-CHAVE: Iconoclastia. Cinema. Cinema para crianças. Pedagogia. Historia da educação.

\begin{abstract}
Iconoclasm is a part of a history of images in education that takes into account multiple senses. In the many, intense passions triggered by images, iconoclasm stands out as a strong feeling that attaches enormous powers to images -a reverence and fear that leads to the point of destroying them. Yet, it has been scarcely studied in the history of education. In this paper, I would like to propose a first approach to iconoclasm through an analysis of two films on children and schooling from the 1930s, Emil und die Detektive (Germany, Gerhard Lamprecht, 1931) and Zéro de conduite (France, Jean Vigo, 1933), which include several scenes in which monuments and other icons of traditional authorities are desecrated. Through these films, I would like to reflect on the ambivalence of the iconoclast gesture in the history of pedagogy, as a history of revolt against constituted authorities but also as a movement that remains trapped in a circle of "fascination, repulsion, destruction, and atonement ... generated by the forbidden-image worship" (LATOUR, 2010, p.70) -a circle that might need to be questioned if another politics of the visual is to be fought for.
\end{abstract}

KEYWORDS: Iconoclasm. Film. Children's films. Pedagogy. History of education.

\footnotetext{
${ }^{1}$ Investigadora Titular - Departamento de Investigaciones Educativas (DIE-CINVESTAV) - Ciudad de México México. E-mail: idussel@gmail.com. ORCID: http://orcid.org/0000-0003-3983-3985.

Submetido em: 15/11/2016 - Aceito em: 06/02/2017
}

\section{(C) ETD-Educação Temática Digital Campinas, SP v.19 n.2 p.437-455 abr./jun. 2017}




\section{RESUMEN}

La iconoclastia es parte de una historia de las imágenes en la educación que toma en cuenta la multiplicidad de los sentidos. Entre las muchas e intensas pasiones suscitadas por las imágenes, se destaca la iconoclastia como un sentimiento fuerte que otorga mucho poder las imágenes -una reverencia y un miedo que lleva hasta el límite de destruirlas. Sin embargo, ha sido poco estudiada en la historia de la educación. En este artículo, me gustaría proponer una primera aproximación a través del análisis de dos películas infantiles de la década de 1930, Emil und die Detektive (Alemania, Gerhard Lamprecht, 1931) y Zéro de conduite (Francia, Jean Vigo, 1933), que incluyen varias escenas en las cuales se profanan monumentos y otros íconos de las autoridades tradicionales. A través de estas películas, me gustaría reflexionar sobre la ambivalencia del gesto iconoclasta, como una historia de revuelta contra las autoridades constituidas pero también como un movimiento que queda atrapado en un círculo de "fascinación, repulsión, destrucción, expiación... generado por la adoración de la imagen prohibida” (LATOUR, 2010, p. 70), un círculo que debería cuestionarse si se quieren abrir caminos para otras políticas y pedagogías de lo visual.

PALABRAS CLAVE: Iconoclastia. Cine. Cine infantil. Pedagogía. Historia de la educación.

\section{INTRODUCCIÓN}

En este ensayo, me gustaría presentar algunas reflexiones y preguntas sobre los vínculos entre iconoclastia y pedagogía. Me gustaría seguir tres líneas de pensamiento en torno a este problema: la pedagogía, el cine y particularmente el cine infantil de los años '30. Estas tres líneas de pensamiento son cabos o hilos para seguir indagando, y no pilares de una nueva estructura teórica o historiográfica. Una fuente de inspiración para lo que quiero realizar en este texto es un poema visual del artista chileno Diego MAQUIEIRA, que fue presentado en la Bienal de Sao Paulo en 2012. En la superficie de una fotocopia de una foto que, según se dice en otro poema de la serie, es de una bailarina francesa de 1928, MAQUIEIRA dice que "Los cabos sueltos no son para atar lazos/Sólo están para dar señales" (Poema Franja de la Totalidad, incluido en El Annapurna, 2012). Mi intención no es atar lazos, sino dar algunas señales sobre cómo aproximarnos a las imágenes como ámbitos o espacios de afectividad, como materialidades y cuerpos en un régimen visual. A través del abordaje de la iconoclastia en la pedagogía y el cine, me gustaría también problematizar el gesto del martillo o la antorcha que destruye imágenes, un gesto que ha sido dominante en las teorías y aproximaciones críticas a lo visual pero que, por ese dominio, no siempre ha sido suficientemente interrogado (LATOUR, 2010).

La iconoclastia permite pensar simultáneamente sobre las cualidades materiales, objetuales y afectivas de la imagen. En las muchas e intensas pasiones suscitadas por las imágenes (LATOUR, 2010), la iconoclastia se destaca como un sentimiento fuerte que confiere enormes poderes a las imágenes: puede decirse que es movida por una reverencia y un miedo que lleva al punto de destruirlas. La presencia de las imágenes se vuelve

\section{(C) ETD-Educação Temática Digital Campinas, SP v.19 n.2 p.437-455 abr./jun. 2017}


insoportable; su cualidad material provoca reacciones que incluyen sentimientos "negativos" como el odio y la sospecha, y energías y acciones destructivas. Las imágenes consideradas ofensivas, ídolos, tienen que ser censuradas, denunciadas, castigadas (MITCHELL, 2006, p. 126), y aquí es donde la mano que levanta el martillo o la antorcha ingresa a la escena. La iconoclastia da indicios sobre el poder de las imágenes, su eficacia, la economía de afectos y representaciones en la que circula. En este aspecto, es importante subrayar la ambivalencia de ese gesto iconoclasta: el iconoclasta participa del placer que da la imagen, del exceso que provoca, y en ese acto, refuerza los mismos supuestos de la iconofilia, que sostiene que las imágenes tienen enorme poder y que no hay distinción entre ellas y el referente. Como dice la filósofa e historiadora del arte Marie-José MONDZAIN, "la iconoclastia y la iconofilia no están opuestas la una a la otra, como sí lo estaría una adopción generalizada e incondicional del retrato y una radical an-iconicidad" (MONDZAIN, 2002, p. 177, traducción propia). No se trata, entonces, de un gesto que está por fuera del sistema que critica, sino que en muchos sentidos es su reafirmación.

Por otra parte, la iconoclastia plantea el problema de las fronteras entre lo que puede verse y lo que no puede ser visto. El motivo de la lucha o de la disputa alrededor de las imágenes es menos su esencia que las relaciones de dominación del espacio público (BELTING, 2012). “¿Quién es un idólatra? Siempre es el otro, o más particularmente, el pueblo", dice Marie-José MONDZAIN (2002, p. 179). Y agrega: "la historia de los ídolos siempre incluye algún asesinato" (p. 178). No debería olvidarse que el término idolatría conlleva "una historia pesada de conquista colonial", "la justificación de genocidios y represiones de todo tipo" (p.179). "Nuestras" imágenes son verdaderas, pero las de los otros (los ídolos, los idólatras) pretenden serlo de manera ilegítima. El iconoclasta "cumple una función en la delimitación y en la gestión del espacio público; regula distancias, autoriza presencias" (OTERO, 2012, p. 14).

En el ámbito educativo, el gesto de muchos educadores progresistas o críticos siguió la misma trayectoria iconoclasta. En sus peleas con las jeraquías tradicionales, las nuevas autoridades fueron quienes se arrogan el poder de dirigir el juego de imágenes, producir una nueva regulación de las distancias y renovar la búsqueda de neutralizar a las imágenesídolo. En el último siglo, en la historia de la educación estas nuevas autoridades tomaron dos caminos: las de proponer, contra las imágenes religiosas, las imágenes seculares del panteón nacional o científico o de la cultura de masas, y las de defender el predominio de los códigos abstractos que evacúan el cuerpo o el exceso de las imágenes, una de cuyas formas es la operación crítica que presenta a las imágenes como meros significantes

\section{(c) ETD-Educação Temática Digital Campinas, SP v.19 n.2 p.437-455 abr./jun. 2017}


(OTERO, 2012, p. 17). La iconografía secular y el diagrama de Venn fueron los dos polos en torno a los cuales se movió la producción de imágenes escolares (FELDMAN, 2010).

En el ámbito educativo, la pregunta sobre la iconoclastia abre interrogantes sobre qué se ha vuelto visible, cómo lo ha hecho, con qué instrumentos, bajo qué supuestos, al mismo tiempo que permite interrogarse sobre lo que se volvió invisible o se reprimió. Siguiendo la crítica de Foucault sobre los límites de la hipótesis represiva del poder, puede decirse que la iconoclastia no es solamente una acción de censura o represión, sino también de producción de nuevas imágenes, de nuevos regímenes visuales. Tom MITCHELL, uno de los más importantes estudiosos de la cultura visual, señala que "la iconoclastia es más que sólo la destrucción de imágenes; es una "destrucción creativa", en la que una imagen secundaria de desfiguración o aniquilación es creada al mismo tiempo que la imagenobjetivo es atacada" (MITCHELL, 2006, p. 18). También apunta que "[I]a destrucción de una imagen puede ser también una imagen por propio derecho" (MITCHELL, 2006, 19, nota a pie 30). Crear imágenes iconoclastas: hay en esa producción muchos elementos disímiles, sobre lo que volveré más adelante.

Propongo, entonces, abordar los vínculos entre iconoclastia y pedagogía, para poner de manifiesto la complejidad y la ambivalencia de ese gesto iconoclasta, y contribuir a repensar la posición y la forma de la crítica. Las tres líneas de análisis que propongo son: una revisión de los vínculos entre iconoclastia y pedagogía, una aproximación a los vínculos entre la iconoclastia y el cine, y un análisis de lo que ofrecen dos películas infantiles que hablan de un clima de época de los años '30, de la radicalidad de las nuevas pedagogías y la entronización del niño como sujeto educativo en el siglo $X X$, que constituyen un legado importante para la imaginación crítica a lo largo de todo el siglo. En la última sección, se ofrecen algunos comentarios finales sobre el gesto iconoclasta en la pedagogía.

\section{PRIMERA LÍNEA DE ANÁLISIS: LA ICONOCLASTIA Y LA PEDAGOGÍA}

En mi aproximación, un primer encuentro con la relevancia de la iconoclastia no sólo para la historia de la educación sino también para entender la escolarización contemporánea tuvo lugar a través del trabajo de Laura MALOSETTI COSTA sobre la profanación de monumentos e íconos patrióticos en el espacio pedagógico público argentino, incluyendo escuelas y parques urbanos (2008). MALOSETTI tomó como punto de partida un video amateur perturbador, conocido ese mismo año a través de las redes sociales, que mostraba a un grupo de estudiantes en una clase en escuela secundaria pública de la Ciudad de Buenos Aires que persistentemente se burlaban de su profesora de

\section{(c) ETD-Educação Temática Digital Campinas, SP v.19 n.2 p.437-455 abr./jun. 2017}


Literatura, parodiándola e incluso prendiéndole momentáneamente fuego a su cabello mientras ella seguía dando su lección pretendiendo que nada pasaba. El video fue grabado en el celular de un estudiante, quien actuó como "director de cámara" pidiéndole a sus compañeros que se dispongan en ciertos lugares del aula para poder ser mejor vistos, o demandando repetir ciertas escenas de burla a la profesora para que salieran mejor enfocados. Este video, como era de esperarse, causó mucho revuelo en los medios y debates pedagógicos; previsiblemente, alimentó el "pánico moral" por el supuesto salvajismo de los jóvenes y la caída en desgracia de la autoridad pedagógica de los profesores. También abrió un debate sobre el uso de las nuevas tecnologías y la posibilidad de ampliar las esferas de crueldad al expandir estas escenas en su circulación fuera del aula, incluyendo la recreación que se hace en este artículo.

Sin embargo, lo novedoso del análisis de MALOSETTI es que procuró no sumarse a los discursos conservadores, y propuso poner al video amateur en serie con otras imágenes de profanación de monumentos, una serie que vincula el desafío y parodia de las autoridades pedagógicas a la de los héroes nacionales, particularmente a quienes, hacia finales del siglo XIX, sostuvieron visiones racistas de los pueblos originarios, como los ex presidentes Julio Argentino Roca (1843-1914) o Domingo F. Sarmiento (1811-1888). Para MALOSETTI, hay un hilo que conecta las viejas y nuevas profanaciones, una conexión que abrió una especie de caja de Pandora cuando instituyó la destrucción y profanación de las imágenes del poder como el único gesto posible de revuelta. Su argumento, que es parte de su postura crítica sobre la historia visual argentina, no es sostener a las viejas autoridades sino cuestionar la forma y dirección que toma esta destrucción de imágenes.

Como alternativa, MALOSETTI sugiere mirar a otros gestos iconoclastas disponibles en la escena artística y política argentinas, como las acciones del Grupo GAC (Grupo de Arte Callejero), un colectivo artístico que organizó protestas sobre la ubicación central en el espacio público de las estatuas y la figura de Julio Argentino Roca como símbolo nacional. Roca fue presidente y jefe de la así llamada Conquista del Desierto, una campaña de exterminio de las poblaciones indígenas y de ocupación de la Patagonia, entre 1878 y 1885. Las estatuas que lo celebran se ubican en lugares centrales de la ciudad de Buenos Aires y otras ciudades importantes argentinas, y hasta hace muy poco fue la figura que ilustraba el billete de 100 pesos (también hasta hace poco el de más alta denominación de la moneda argentina). El GAC jugó con el apellido del general, proponiendo nuevas ubicaciones para estos monumentos y sobre todo abriendo reflexiones y debates sobre la persistencia del racismo y la violencia hacia las poblaciones marginalizadas en tiempos contemporáneos. En

\section{(c) ETD-Educação Temática Digital Campinas, SP v.19 n.2 p.437-455 abr./jun. 2017}


sus intervenciones, vinculó a Roca y el genocidio de los pueblos originarios con la continuidad de la explotación y saqueo de estos pueblos y de los recursos naturales por las corporaciones transnacionales ubicadas en la Patagonia, como Repsol y Benetton, sin cancelar estos debates por la demonización de algunas figuras. EI GAC escenifica acciones que cuestionan el status quo, abriendo otras posibilidades para la representación política y simbólica. $^{2}$

MALOSETTI se pregunta cómo es posible que adolescentes en la Argentina contemporánea puedan hacer este tipo de actos de profanación de las autoridades pedagógicas de la manera en la que lo hacen, prendiendo fuegos o iniciando incendios, y su pregunta no pasa por reconstruir sentidos por fuera de la imagen sino por rastrear con qué serie de imágenes se vincula este video amateur. Siguiendo a MITCHELL (2002), le preocupa entender la producción visual de lo social, y no tanto ni sólo la condición social de la imagen o su atravesamiento por discursos sociales. Puede decirse que el gesto iconoclasta busca producir algunas imágenes que, por sí mismas y dentro de una serie de imágenes que operan en nuestra cultura, operan algunos efectos. MALOSETTI cree que hay que interrogar esta historia más larga de la violencia contra las imágenes y los símbolos, que es la historia de un modo de procesar y criticar a las autoridades que no encuentra otras formas, podríamos llamarlas más creativas, políticamente más democráticas y pedagógicamente más productivas, para pelear por órdenes diferentes. A la autoridad de la profesora de escuela, se opone en el video la autoridad de la destrucción y la "celebración del hundimiento de lo vigente" (GROYS, 2012, p. 63) pero sin que quede claro qué otras autoridades se instalan (¿la del alumno-director de cámara? ¿la del espectáculo de la burla y la humillación?). La imagen que se busca producir es el incendio del profesorado y de las viejas instituciones escolares. Es una imagen violenta y hasta temible, si la unimos a otras escenas de quema de libros y bibliotecas o a la persecución de las figuras profesorales en tiempos recientes tanto dictatoriales como neoliberales, pero no es una imagen descolgada o por fuera de un régimen visual, sino que viene de lugares ya transitados en la historia cultural argentina, así como de la de muchos otros países que han tenido sus Torquemadas. Esa serie que construye MALOSETTI no es la más habitual en la historia de la educación y en la pedagogía crítica, que prefiere ver a la escuela y los profesores como los inquisidores, y a los niños como sus víctimas; sin embargo, cabría seguir el hilo que propone, para desanudar esas asociaciones y repensar cómo funcionan en este régimen visual y político las distintas posiciones, a qué series se suman, qué efectos producen esos gestos.

\footnotetext{
${ }^{2}$ Véase su sitio: grupodeartecallejero.blogspot.com

(C) ETD-Educação Temática Digital Campinas, SP $\quad$ v.19 $\quad$ n.2 $\quad$ p. 437-455 abr./jun. 2017
} 


\section{SEGUNDA LÍNEA DE ANÁLISIS: LA ICONOCLASTIA EN EL CINE}

Propongo volver al cine para una segunda línea de interrogación, considerando su lugar central en la iconoesfera del siglo XX. En la problematización del gesto iconoclasta, en sus vínculos con la pedagogía y el cine, hay que considerar al propio cine como iconoclasta. En este apartado, seguiré de cerca los argumentos del historiador y crítico de arte Boris GROYS, que tiene un ensayo donde discute al cine como estrategia iconoclasta. Me interesa poner sus reflexiones en relación con la historia de la educación y con la pedagogía para pensar, en la sección siguiente, sobre ciertas imágenes iconoclastas que se instalaron como 'nuevos ídolos' de la educación.

Como dice Boris GROYS (2012), el cine nunca estuvo en la esfera de lo sagrado: su emergencia como arte mecánica y popular lo puso rápidamente del otro lado, como parte de una época crecientemente secularizada. Dice GROYS que, en una primera aproximación, puede señalarse que el cine monta escenas iconoclastas, pero no es iconoclasta él mismo (p.55).

Sin embargo, hay aspectos en los que el medio y el lenguaje cinematográfico sí puede considerarse iconoclasta. Por un lado, está su crítica a otros medios y artes como la pintura o la escultura, que forma parte de sus estrategias específicas. "Como medio del movimiento, el cine manifiesta a menudo y gustosamente su superioridad frente a otros medios cuyos logros más elevados se obtienen bajo la forma de tesoros culturales y monumentos inmóviles, y lo hace celebrando y escenificando la destrucción de estos monumentos" (GROYS, 2012, p. 62). Como se verá más abajo, algunos de los ejemplos que se plantean en la siguiente sección dan cuenta de esta estrategia iconoclasta propia del cine.

La cuestión del movimiento como eje singular del lenguaje cinematográfico es también iconoclasta en sí misma. GROYS plantea que la iconofilia es ante todo contemplativa: para adorar a los dioses, hay que rendirse frente a ellos, admirarlos, someterse, y sacarlos del contacto cotidiano. Sin embargo "para el cine, no se da nada de sagrado que deba o pueda ser protegido de esta inclusión en el movimiento general. Todo lo que se muestra en el cine es transferido a movimiento, siendo así profanado" (GROYS, 2012 , p. 62). Hay en estas ideas muchos ecos de Walter Benjamin y su percepción de que el cine y las artes de la reproducción mecánica rompen el aura y el vínculo cultual (de culto) con las imágenes, y las ponen en una circulación horizontal que las desacraliza, las profana. Lo que suma GROYS es pensar al propio lenguaje cinematográfico y su demanda de replicar

\section{(C) ETD-Educação Temática Digital Campinas, SP v.19 n.2 p.437-455 abr./jun. 2017}


el movimiento de la vida, así como incluir el poder de la circulación como metáfora pregnante de lo social que no deja nada al margen.

Pero también está su lugar crecientemente simbólico como representante de una modernidad secular. El cine se entroniza como un ícono más, sumando a mediados del siglo $\mathrm{XX}$ todo un sistema de estrellas y divas que vienen a representar a los nuevos dioses. En esa acción, el cine preparó la dirección del próximo gesto iconoclasta, que se dirigió contra el cine mismo. Varias de las corrientes renovadoras del cine (como las videoinstalaciones de Richard Serra o las películas de Andy Warhol, pero también el realismo de los años '60 y '70) buscaron detener y diseccionar el lenguaje cinematográfico oficial (GROYS, 2012, p. 55). El cine político, por ejemplo, buscó sacudir al espectador y sacarlo de la contemplación pasiva. GROYS dice que esta crítica iconoclasta llevó en muchos casos a la congelación del cine mismo, a una especie de martirio, que quizás anuncie, si no un fin, al menos una transformación del cine en otro medio.

A la par que estas preguntas sobre su carácter iconoclasta, cabe preguntarse por su función hoy, en el marco de un régimen visual y político-económico en que estos gestos críticos parecen haber sido apropiados por la cultura oficial. Retomando algo de lo señalado por MALOSETTI, cabe preguntarse por qué efectos produce el cine en el marco de regímenes visuales que instalan como norma la instauración perpetua de la novedad y la creatividad, y donde el nuevo ícono pasa precisamente por la aniquilación de lo viejo. Dice Jacques Rancière:

\footnotetext{
"todas las formas de crítica, de juego, de ironía que pretendían perturbar la circulación común de las imágenes, ¿̇no han sido ya anexadas por esta circulación? El cine moderno y crítico ha pretendido interrumpir el flujo de las imágenes mediáticas y publicitarias suspendiendo las conexiones de la narración y el sentido. (...) [Pero] los procesos del corte y del humor se han vuelto lo básico de la publicidad, el medio por el cual produce a la vez la adoración de sus íconos y la buena disposición hacia ellos que nace de la posibilidad misma de ironizar." (RANCIÈRE, 2003, p.36).
}

Habría que pensar, entonces, si la potencialidad de crítica democrática que contenía el gesto iconoclasta no se ve menguada cuando sus estrategias son utilizadas tan extensamente como las formas más "honestas" de presentar y vender un producto. ¿Qué lugar queda para la iconoclastia como carnaval democrático, como crítica al orden instituido, cuando es apropiada desde los lenguajes dominantes? ¿Qué relación con la cosa común, con alguna definición de verdad como criterio compartido, se estructura a partir de la ironía como género o como "tono" de vínculo con lo social y lo político? Son preguntas

\section{(C) ETD-Educação Temática Digital Campinas, SP v.19 n.2 $\quad$ p.437-455 abr./jun. 2017}


abiertas, que quisiera mantener como inquietud para abordar algunos ejemplos del cine infantil de la década de 1930 y sobre las imágenes que ofreció para criticar a las autoridades instituidas, imágenes que se convirtieron en icónicas de la rebelión y la crítica pedagógicas del siglo XX.

\section{TERCERA LÍNEA DE ANÁLISIS: LA ICONOCLASTIA EN EL CINE INFANTIL EN LOS AÑOS '30}

La tercera línea de pensamiento de estos 'cabos sueltos' sobre iconoclastia y pedagogía se vincula, entonces, al cine para niños. Quisiera retomar algunas escenas de dos películas infantiles, la primera una realizada en la República de Weimar, Emil und die Detektive (Alemania, Gerhard LAMPRECHT, 1931), y la segunda una francesa, Zéro de conduit (Francia, Jean VIGO, 1933), porque permiten analizar cómo el cine participa de esta producción de nuevos ídolos mediante la destrucción de los viejos.

'Emil und die Detektive' probablemente sea una de las historias infantiles más exitosas del siglo $X X$, que circuló a través de numerosas plataformas que van desde el libro publicado en 1929 por Erick KÄSTNER hasta películas alemanas, con versiones británica, norteamericana, argentina y japonesa, hasta dibujos animados, series de TV y obras de teatro por el National Theatre en Inglaterra en 2014. Pero su éxito puede verse también en la amplitud de los estilos y tradiciones que se involucraron en estas circulaciones: el documental social, el cine expresionista alemán, las películas de Disney de la Guerra Fría, la comedia musical, entre muchos otros. 'Emil' cuenta la historia de un niño de un pueblo alemán que por una disrupción del viaje a la casa de su abuela, al modo de Caperucita, es lanzado a los peligros de la gran ciudad (Berlín, locación estelar a lo largo del siglo XX para ejemplificar las ansiedades y miedos de la vida urbana). En esa jungla urbana, Emil encuentra en la solidaridad y la auto-organización de otros niños el poder para superar los fracasos y miserias de los adultos. En muchos sentidos, la historia organiza un modo de hablar y mostrar a la infancia: los niños son criaturas listas, inteligentes, creativas y con recursos para moverse en un mundo hostil, imagen que, aunque ya estaba presente en la literatura infantil del siglo XIX, no cesará de expandirse y crecer en las películas y televisión de las décadas siguientes (WOJCIK-ANDREWS, 2000).

Quisiera presentar algunos comentarios breves sobre la versión de 1931, la primera que pasa del libro a la pantalla, que está muy próxima a los movimientos pedagógicos de su época. Gerhard LAMPRECHT, el director, ya había producido algunos documentales sobre la situación de la infancia y las clases trabajadoras en la década de 1920 (por ejemplo, Los

\section{(c) ETD-Educação Temática Digital Campinas, SP v.19 n.2 p.437-455 abr./jun. 2017}


llegítimos, de 1926), y, aunque conservador, estaba cercano al trabajo de los socialdemócratas sobre las condiciones de vida de los niños pobres. La película combina géneros distintos como el documental social sobre la vida en Berlín y la slapstick-comedy o comedia de enredos y absurdos. Billy WILDER fue el autor del guión, que fue uno de sus primeros trabajos en la productora UFA, un gran polo de producción cinematográfica de entreguerras.

La escena inicial de la película muestra a tres niños jugando a ser bandidos, poniéndose antifaces y colocando un bigote falso, un casco y una pequeña cartera en una estatua en un parque (DIXON, 2012, p. 10). Los niños se burlan de la figura de autoridad, y cuando están divertidos llega el policía, lo que los obliga a salir corriendo. La contraposición entre la estatua fija y el movimiento de los niños muestra algo de lo que GROYS señala como el gesto iconoclasta del cine sobre otras artes. Es una escena que muestra todavía el carácter de transición de estas películas entre el cine mudo y el cine sonoro, que había sido adoptado en las películas alemanas sólo un año antes. En la escena, no hay sonido diegético, es decir, que emerge de la propia situación, sino que la música reemplaza a las risas y ruidos de la infancia. La perspectiva de la cámara es predominantemente la de los niños, por ejemplo en los planos en los que se muestra al policía que llega a evaluar los daños hechos a la estatua y se establecen paralelos entre una y otra figura (la estatua y la policía), intercalados con planos medios de los cuerpos infantiles escondidos y primeros planos de la mirada de Emil.

La escena ha sido descripta por la crítica británica Bryony DIXON como "no central para la trama" (BRIXON, 2012, p. 10), en gran parte porque no vuelve a ser recuperada. No se dan más datos sobre la estatua, ni por qué los niños se ensañan con ella. Sin embargo, es más central de lo que parece, ya que esta travesura inicial de profanar la estatua en un parque público se vuelve la causa por la que Emil, ante sus desventuras, evita tomar contacto con la policía y se afirma en un mundo de solidaridad infantil como el que encuentra en Berlín. Este grupo de niños va a mostrar que "con coraje, solidaridad e imaginación, los niños -tan frecuentemente subestimados- pueden enfrentar cualquier aventura posible" (WILLIG, 2012, p. 5). Esta imagen de los niños profanando una estatua del benefactor de la ciudad se vuelve una "imagen secundaria" que se torna "un ídolo por propio derecho" (MITCHELL, 2006, p. 21). Podría decirse que es la posibilidad de burlarse de la estatua, ridiculizarla, cuestionar la autoridad adulta, lo que va a liberar a Emil para encontrar su independencia, su propio poder.

\section{(C) ETD-Educação Temática Digital Campinas, SP v.19 n.2 p.437-455 abr./jun. 2017}


Es interesante que esta escena no está presente en las distintas remakes de la película. El ataque iconoclasta sobre la estatua pública es borrada o censurada en la versión de Disney de 1964 (dirigida por Peter TWEKBURY), así como en las dos versiones alemanas de 1954 (dirigida por Robert STEMMLE) y 2001 (dirigida por Franziska BUCH), así como de la versión argentina de 1950. En muchos casos, se la reemplaza con una travesura o incomprensión de la policía y la sociedad; por ejemplo, en la versión del 2001 lo que causa el distanciamiento de la policía es el acto de Emil de abrir (profanar) un repositorio público de descarte y reciclado de ropa, que quiere vender para una buena causa: conseguir dinero para que su padre pueda ir a su nuevo trabajo. La única excepción a esta censura de la profanación inicial es la versión inglesa de la película, de 1935, casi idéntica a la inicial alemana. En el film de 1954, dirigido por STEMMLE y ubicado también en Berlín, la travesura es algo más dramática, ya que implica liberar a una foca encerrada en un acuario para soltarla en el mar. El acarreo de la foca lleva al robo de un carro o carretilla oficial del Correo Alemán, un delito federal de mayor envergadura que es el que pone a Emil al margen de la ley; pero esta travesura no involucra una burla o crítica abierta a la autoridad sino que apela a una norma más abstracta e impersonal como los derechos de los animales. El hecho de que este "crimen" inicial no se retome sugiere, como señala el crítico inglés Michael ROSEN (2012) que "este era un paso demasiado avanzado para la industria del entretenimiento infantil en la Gran Bretaña del 1930" (p.3), y en muchas otras industrias nacionales del cine.

La presencia de esta escena de profanación de la estatua pública en la película alemana de 1931, y su censura posterior, muestra la singularidad de la vida berlinesa de la República de Weimar, "la cercanía deliberada de la calle como locación política, las manifestaciones y protestas de esos años" (WILLIG, 2012, p. 6). El clímax de la película, siguiendo a la historiadora del cine Caren WILLIG, llega con la puesta en escena de multitudes de niños que marchan en solidaridad con Emil y derrotan al villano enemigo. No es posible mirar estas escenas de los movimientos de masas de los "débiles" (los niños) que se volvieron "fuertes y superiores" en el Berlín de Weimar sin asociarlo con el ascenso del nazismo, pero volviendo a pensar en la época en la que había distintas posibilidades contenidas, puede decirse que sobre todo refiere a la fuerte politización de la sociedad y la infancia en aquel tiempo: no solamente había Juventudes Hitlerianas sino también socialistas y comunistas. La similitud en la politización, a pesar de todas sus diferencias, es señalada por el historiador J.D. STAHL (1986), quien compara el libro Emil und die Detektive, de Erich Kástner, un antifascista cuya obra fue prohibida por el nazismo, y otros libros infantiles pro-nazis, y encuentra que coinciden en otorgar a la infancia un lugar de

\section{(c) ETD-Educação Temática Digital Campinas, SP v.19 n.2 p.437-455 abr./jun. 2017}


esperanza y renovación del mundo, y de celebración de las organizaciones juveniles como las que portan el germen de lo nuevo.

Quisiera retomar el gesto iconoclasta de profanar una estatua pública, un acto que marca el camino posterior de la trama y las aventuras de Emil, como una imagen que, quizás por censurada y reprimida, queda con fuerza en el imaginario social sobre la infancia y la educación en el siglo XX, como un horizonte al que aspirar y un carnaval que celebrar. Junto a sus amigos, Emil se burla de la figura de autoridad, y es esa burla la que le permite salir a la gran ciudad y encontrar a sus amigos detectives. Podría hacerse un paralelo con el gesto de los adolescentes argentinos que se burlan de su profesora en el video analizado por MALOSETTI, aunque en el caso de Emil se defenestraba a un símbolo y no a un cuerpo presente; como ya se señaló, tampoco es claro qué se sigue de esa quema y humillación en el video amateur de 2008, mientras que en Emil se deriva en una afirmación del poder infantil y de nuevos parámetros de justicia y participación en lo público.

Esta ridiculización ${ }^{3}$ puede verse también en los gestos iconoclastas de la película Zéro de conduite (Francia, Jean VIGO, 1933), uno de los filmes más interesantes y agudos de crítica a la escuela. Ha sido considerada una película anarquista, un "film iconoclasta" que trae vientos de libertad al cine y la pedagogía (VANOBBERGEN ET AL, 2014, p. 446). Jean VIGO estaba cercano a las críticas escolanovistas de las primeras décadas del siglo XX, y su película incluye varias escenas en las que íconos de la autoridad tradicional son profanados; por ejemplo, el profesor y el director de la escuela son ridiculizados, los libros son tirados fuera del aula, el preceptor es paseado atado a una cama, entre muchas otras escenas que muestran la revuelta infantil. Zéro de conduite es más radical en su crítica social que Emil: produce un retrato agudo y lacerante de lo que la escuela hacía con, para y hacia los cuerpos infantiles (CORRIGAN, 1988), de la violencia que estaba en su base, y de las exclusiones y marginaciones que orquestaba. En línea con Emil, la película de VIGO es muy clara respecto al poder de la solidaridad y organización infantil para confrontar los abusos

\footnotetext{
${ }^{3}$ Hay, sin embargo, un aspecto que destaca Tom MITCHELL sobre el carácter iconoclasta de la caricatura y la burla como forma de des-figuración que habría que tomar en cuenta: "se toma el estereotipo y se lo deforma o desfigura, exagerando algunos rasgos o convirtiendo la figura del Otro en algún objeto subhumano para ridiculizarlo o humillarlo. (...) Una estrategia típica de la caricatura es tomar algunos rasgos humanos en términos de una forma de vida "baja", generalmente animal", lo que opera junto a la acusación de los iconoclastas de que "los idólatras están adorando la imagen de los brutos o ignorantes" (MITCHELL, 2006, p. 20). "En este proceso [de crítica iconoclasta], los cuerpos humanos reales se convierten en daño colateral" (idem). Esta idea de que la caricatura des-humaniza a los cuerpos podría seguir pensándose para este y otros casos, aunque sin perder de vista el potencial democrático de la risa y el carnaval señalado, entre otros, por BAKHTIN.
}

\section{(c) ETD-Educação Temática Digital Campinas, SP v.19 n.2 p.437-455 abr./jun. 2017}


de los adultos. "Juntos venceremos": los dos filmes parecen alinearse con los movimientos de izquierda de aquel momento, que veían a los niños como seres políticos por antonomasia (MILLEI, 2015).

Jean VIGO usa también elementos del documentalismo social y la crítica política, como LAMPRECHT, el director de Emil, y hace guiños a la slapstick-comedy, "para poner en escena verdaderas orgías de destrucción, demoliendo todo lo que se para o cuelga sin movimiento, incluyendo los tesoros culturales tradicionalmente reverenciados, y sin dejar de alcanzar a espectáculos públicos como el teatro y la ópera que corporizaban el espíritu de la vieja cultura" (GROYS, 2008, p. 72). En esa dirección, muestra las posibilidades del cine como medio iconoclasta que desacraliza a los íconos y los incluye en una circulación general horizontalizada. Como cineasta, VIGO resulta mucho más audaz que LAMPRECHT, y quiere demostrar que "como medio de movimiento, el film es superior a otros medios" (ídem). En las películas de VIGO, el cine es iconoclasta en su relación con las otras artes: las pinturas, los monumentos, las imágenes religiosas. La revolución de los niños tiene que dar vuelta los símbolos escolares y soltar amarras con las viejas jerarquías. Apoyados por un profesor díscolo, los niños salen del salón y de la escuela a mirar el mundo, incluyendo a una joven mujer que pasa, sensual, por la calle. La escena final, cuando los niños escapan por los techos, muestra la inversión de reglas y de posiciones: los niños tienen por fin el control del ritual escolar y de la escena. Siguiendo a GROYS, y como fue señalado en el apartado anterior, también se produce un cambio de escenarios, una ruptura con los muros de la escuela, una opción por la vita activa de la marcha y del caminar por los tejados contra la vita contemplativa del aula tradicional (GROYS, 2012).

VIGO despliega en esta crítica a la escuela el gesto iconoclasta de romper con los símbolos cuasi-religiosos de la escuela, que incluye tanto una apertura al mundo como una crítica feroz de lo que se ofrece al interior de la escuela. Hay que burlarse de los crucifijos y de las viejas autoridades profesorales; en una escena casi sacrílega, el prefecto dormido es atado a una cama, que es puesta en posición vertical, y los niños gritan y juegan a la guerra de almohadas con la imagen del prefecto colgando, aunque todavía dormido. La escena es humorística pero también violenta: los oprimidos reaccionarán con fuerza idéntica a la opresión. Los niños en el poder serán una autoridad inquietante, perturbadora.

Pero, mirando hacia las décadas siguientes, podría decirse que lo que se instala en el lugar de los viejos símbolos, a partir del escolanovismo y la crítica radical a la escuela, no es la an-iconicidad (como señaló MONDZAIN) sino otros símbolos, los de la revuelta infantil y los del código abstracto, los que en el largo plazo serán mucho más fuertes que las

\section{(C) ETD-Educação Temática Digital Campinas, SP v.19 n.2 p.437-455 abr./jun. 2017}


imágenes inquietantes de la revuelta. Me interesa detenerme en los códigos abstractos por un momento. Para Bruno LATOUR (2010), la abstracción es un modo de neutralizar el exceso de las imágenes. Las inscripciones científicas, para muchos, no son siquiera imágenes: "llamarlas imágenes, inscripciones, representaciones, es ya en sí un gesto iconoclasta" (LATOUR, 2010, p. 74). "Y sin embargo," continúa Latour, "sin esos instrumentos enormes y costosos, sin amplios grupos de científicos, sin vastas cantidades de dinero y largo entrenamiento, no podría verse nada en tales imágenes. Es por todas esas mediaciones que pueden ser capaces de ser tan objetivamente verdaderas" (LATOUR, 2010, p. 75). La objetividad de las imágenes científicas, claro está, no reside en ellas mismas sino en estas redes que las producen y las sostienen como verdaderas; lo interesante de esta crítica latouriana es que desmonta la ilusión de in-mediatez, de no mediación, de los códigos abstractos, y los pone en el mismo plano de la iconicidad contemporánea.

En esta misma línea, pueden recuperarse las reflexiones de Daniel FELDMAN sobre los efectos del escolanovismo y el constructivismo en la iconicidad escolar: "[I]a imagen, ahora, funge como un texto para brindar información, apoyar información de otro tipo u organizar información. Esto parece implicar un cambio radical en su utilización y, probablemente, marca la finalización de un modo de presentar/representar el mundo" (FELDMAN, 2010, p.49). El código se come al cuerpo de la imagen, con la intención de regular su poder y de evacuar sus excesos. Quizás habría que pensar que esta forma de instalar el código abstracto, que en el espacio escolar tomó sobre todo el nombre del constructivismo ${ }^{4}$, fue una forma de evacuar la radicalidad del gesto iconoclasta infantil, de domesticar la inquietud, de instaurar una nueva regulación de las presencias y las distancias por parte de los cuerpos en revuelta; algo de eso sugiere FELDMAN (2010). En cualquier caso, no habría que dejar de ver la crítica iconoclasta produce nuevas imágenes e instala, también ella, otros ídolos, que marginan otras formas de presentación y representación del mundo.

\footnotetext{
${ }^{4}$ Una aclaración necesaria: ocupar el nombre del constructivismo no quiere decir que el constructivismo fuera o sea coextensivo con estas formas de manifestación. Hay muchas corrientes, muchas de ellas radicalizadas, que han resistido la evacuación de la politicidad y la afectividad de la infancia. Pero en la vulgata constructivista, dominante sobre todo desde los años '80, la reducción de la niñez a la cognición, y a su vez la reducción de la cognición a la capacidad de dominar códigos abstractos, ha sido un signo distintivo.
}

\section{(C) ETD-Educação Temática Digital Campinas, SP v.19 n.2 p.437-455 abr./jun. 2017}




\section{COMENTARIOS FINALES}

A través de estas reflexiones sobre la iconoclastia y el cine para la infancia de los años '30, busqué abrir interrogantes sobre la ambivalencia del gesto iconoclasta en la historia de la pedagogía, como una historia de revuelta y cuestionamiento a las autoridades constituidas pero también como un movimiento que permanece atrapado en un círculo de "fascinación, repulsión, destrucción, expiación... generado por la adoración de la imagen prohibida" (LATOUR, 2010, p. 70). El recorrido propuesto buscó problematizar este círculo como modo de abrir caminos a otras políticas y pedagogías, más reflexivas sobre sus efectos y sobre sus propias exclusiones. Siguiendo a LATOUR, es importante "documentar, exponer... un cierto movimiento de la mano" tanto en la religión como en la ciencia, en el cual, "cuando la mano se pone a trabajar, siempre es con un martillo o una antorcha, una mano destructiva" (LATOUR, 2010, p. 71). No por casualidad, y en sintonía con lo que señala LATOUR, MITCHELL propone una "idolatría crítica", una "adivinación secular", como un antídoto a "la iconoclastia reflexiva que gobierna el discurso intelectual actual" (MITCHELL, 2006, p. 26).

El gesto iconoclasta se ha vuelto muy común en las películas y series contemporáneas sobre la infancia y sobre la educación, que ridiculizan y se burlan de las figuras adultas. Esta escena de burla y defenestración se repite y se amplifica desde esa época, pero quizás sea tiempo de suspender, aunque sea por un rato, la antorcha, y pensar en las condiciones y efectos de esa imagen.

La revisión de lo que se presenta como iconoclastia en las películas infantiles de 1930 señala la potencia que tuvo esa crítica en su momento, pero también sus limitaciones, no solamente en cómo fue apropiado por gestos ulteriores que evacuaron la radicalidad de la revuelta sino también en su propia dificultad en reconocer su fascinación con las mismas imágenes. Como señala Boris GROYS, "la profanación de los viejos dioses es realizada en nombre de otros dioses más nuevos. El fin de la iconoclastia es probar que los viejos dioses han perdido sus poderes, y por lo tanto no son capaces de defender sus templos e imágenes terrenales" (GROYS, 2008, p. 112).

¿Cuáles fueron, y cuáles son, esos nuevos dioses? Frente a la vieja autoridad profesoral, puede verse que en el cine de los años '30 se entrona a una infancia creativa, autónoma, "lista", sagaz, definida por los psicólogos y pedagogos tanto como por la industria del entretenimiento. $\mathrm{Si}$ en esos años de entreguerra esas posiciones tenían una clara implicación política a la vez que pedagógica, progresivamente, como puede verse en

\section{(C) ETD-Educação Temática Digital Campinas, SP v.19 n.2 $\quad$ p.437-455 abr./jun. 2017}


las distintas versiones de Emil und die Detektive, esas imágenes de infancia van siendo despojadas de sus aristas políticas más radicalizadas, hasta llegar a la escena del video amateur del 2008, en la que el niño-adolescente director de cámara no se inquieta por la escena de burla y se pliega a un régimen que considera al cuerpo de su profesora un "daño colateral", un costo despreciable ante el beneficio de participar del espectáculo de las cámaras y las pantallas.

¿Qué líneas pueden dibujarse entre las iconoclastias de 1930 y las actuales? El "niño", capturado por las industrias del entretenimiento, ha pasado del otro lado de la cámara. Pero, ¿sigue siendo el impulsor de una revuelta? Entre otros cambios que marcan rupturas entre épocas, puede señalarse uno del cual el video amateur es una referencia privilegiada: en la era iconoclasta de los medios digitales, la esfera pública no es más el lugar donde se erigen los monumentos oficiales, y la guerra de las imágenes (GRUZINSKI, 1991) se traslada a nuevos escenarios como YouTube, Facebook o las pantallas de los celulares. Puede pensarse que, si en la década de 1990 las revoluciones en Europa del Este buscaron ocupar y controlar las estaciones de TV y periódicos oficiales (BELTING, 2012), hoy los movimientos anti-sistema buscan crear imágenes que denoten el fin de los ídolos, como la destrucción de las Torres Gemelas el 11 de septiembre de 2001, o la destrucción de los Budas de Bamiyán por los talibanes - pero también la caza de Osama Bin Laden convertida en película y en videojuego tiene un efecto similar, profanador e iconoclasta-. Sin embargo, siguiendo a MALOSETTI, podría preguntarse el vínculo, o la complicidad, de estas formas extremas con un régimen visual más extendido, como el que se ve en el video amateur del 2008 , en el que los cuerpos y las afectividades pasan a ser considerados 'daños colaterales', y donde la responsabilidad ética por el otro es cada vez menos importante. Hay mucho para seguir pensando, pero no estaría mal, como dice el filósofo Miguel MOREY (2014), asumir que estos tiempos no solamente son para celebrar sino que también tienen algo de zozobra.

En tanto, y para concluir, quiero volver a la idea de pensar a partir de cabos sueltos que no atan lazos, sino que dan señales. Las reflexiones vertidas en este artículo requieren seguir pensándose y confrontándose con otras perspectivas, otras series y otras historias. En todo caso, la señal que quisiera dejar es que habría que poner en cuestión el gesto iconoclasta, y evitar plegarse a la reiteración de la misma escena de una infancia excluida y marginada del autoritarismo adulto que el cine planteó en los años '30. Esta escena contenía muchas posibilidades, pero acabó abriéndole el paso a los nuevos ídolos de la autonomía y la creatividad infantiles, evacuados de la revuelta política y conquistados por las industrias del entretenimiento que definen cada vez más una ética y una mirada de la

\section{(c) ETD-Educação Temática Digital Campinas, SP v.19 n.2 p.437-455 abr./jun. 2017}


infancia, ahora adueñada de la cámara. En este contexto, suspender el martillo iconoclasta ayuda a desensamblar lo que se colocó en el último siglo en el lugar de las viejas autoridades del saber, y a plantear algunas dudas y sombras sobre estos nuevos ídolos que se erigen en su lugar, no para reinstalar a lo que se cayó, sino para encontrar nuevos espacios e imágenes para la revuelta.

\section{REFERÊNCIAS}

BELTING, Hans. La idolatría hoy. En: OTERO, Carlos (Ed.). Iconoclastia. La ambivalencia de la mirada. Madrid: La Oficina, p. 77-97. 208 p, 2012.

BESANÇON, Alain. La imagen prohibida. Una historia intelectual de la iconoclasia. Traducción Encarna Castejón. Madrid: Siruela, 2003. 536 p.

BRIXON, Bettany. Emil and the detectives: a faithful remake. In: Emil and detectives. DVD booklet. London: British Film Institute, 2012. p.10-12.

CORRIGAN, Philip. The making of the boy: meditations on what grammar school did with, to, and for my body. Journal of Education, v. 170, n. 3, p. 142-161, 1988.

FELDMAN, Daniel. Enseñanza y escuela. Buenos Aires: Paidós, 2010, 112 páginas.

FOUCAULT, Michel. The history of sexuality. v. 1: An Introduction. New York: Vintage Books, 1990, $168 \mathrm{p}$.

GROYS, Boris. Art Power. Cambridge, MA: The MIT Press, 2008, 187 p.

GROYS, Boris et. al. La iconoclastia como procedimiento: estrategias iconoclastas en el cine. En: OTERO, Carlos (ed.). Iconoclastia. La ambivalencia de la mirada. Madrid: La Oficina. p. 55-78. 208 p, 2012.

GRUZINSKI, Serge. La guerra de las imágenes. De Cristóbal Colón a Blade Runner (14922019). México, DF: Fondo de Cultura Económica, 1991. 222 p.

LATOUR, Bruno. On the modern cult of the factish Gods. Durham and London: Duke University Press, 2010, 168 p. 
MALOSETTI COSTA, Laura. Algunas reflexiones sobre el lugar de las imágenes en el ámbito escolar. Paper presented at EDUCAR LA MIRADA III. CULTURA VISUAL Y EDUCACIÓN, Buenos Aires, p. 2-4, July 2008.

MILLEI, Zsuzsa. The Cultural Politics of 'childhood' and 'nation': space, mobility and a global world. Global Studies of chilhood. v. 4, n.3, p. 137-142, 2014.

MITCHELL, William John Thomas. Showing Seeing: a critique of visual culture. Journal of Visual Culture. London, Thousand Oaks, CA and New Delhi, v. 1, n. 2, p. 165-181, 2002.

MITCHELL, William T. J. What do pictures want? The lives and loves of images. Chicago: The University of Chicago Press, 2005, p. 380.

MONDZAIN, Marie-José. Image, icon, economy. The Byzantine Origins of the Contemporary Imaginary Translated by Rico Franses. Palo Alto: Stanford Univ., 2005, p. 280.

MOREY, Miguel. El lugar de todos los lugares. Consideraciones sobre el archivo. En: Escritos sobre Foucault. Madrid: Sexto Piso, p. 188-212. 384 p, 2014.

OTERO, Carlos. Introducción: La imagen como paradoja. En: OTERO, Carlos (Ed.). Iconoclastia. La ambivalencia de la mirada. Madrid: La Oficina, p. 9-35. p. 208, 2012.

RANCIÈRE, Jaques. Le destin des images. Paris: La Fabrique, 2003, p. 121.

ROSEN, Mike. Emil and the detectives. In: Emil and Detectives. DVD booklet. London: British Film Institute, p. 1-3, 2012.

STAHL, John Deere. Moral Despair and the child as a symbol of hope in pre-world war II in Berlin. Children's Literature, v. 14, p. 83-104, 1986.

VANOBBERGEN, Bruno; GROVESNOR, lan; SIMON, Frank. Jean Vigo's Zéro de conduite and the spaces of revolt. Paedagogica Historica, v. 50, n. 4, p. 443-459, 2014.

WILLIG, Caren. The Zeitgeist of Emil und die Detektive. In: Emil and Detectives. DVD booklet. London: British Film Institute, p. 5-7, 2012.

WOJCIK-ANDREWS, Ian. Children's Films. History, ideology, pedagogy, theory. New York: Garland, 273 p, 2000. 


\section{Agradecimentos}

Agradezco a Patricia Ferrante el impulso para pensar algunas de estas cuestiones, y a los participantes en el simposio sobre Cuerpos e Imágenes en la ISCHE 36 sus comentarios al texto, especialmente a lan Grosvenor, Karin Priem y Lynn Fendler.

También agradezco a Juliana de Favere (UDESC) por la traducción del resumen al portugués.

\footnotetext{
' La revisión gramatical y editorial de este artículo estuvo a cargo de Carmen de los Reyes (DIE-CINVESTAV).
}

(C) ETD-Educação Temática Digital Campinas, SP $\quad$ v.19 $\quad$ n.2 $\quad$ p.437-455 abr./jun. 2017 